\title{
Inclusion or Exclusion? Local Ownership and Security Sector Reform
}

\author{
TIMOTHY DONAIS ${ }^{1}$ \\ Department of Global Studies, Wilfrid Laurier University
}

\begin{abstract}
This paper explores the dynamics of security sector reform (SSR), a term used to refer to efforts made to reform the security structures of states emerging from conflict or authoritarianism. While "local ownership" is increasingly viewed as a necessary element of any sustainable SSR strategy, there remains a significant gap between international policy and practice in this area. In practice, the SSR agenda continues to be driven largely by international actors, with minimal input, let alone ownership, on the part of either governments or civil society within reforming states. Indeed, the notion of local ownership has come to serve as much as a disciplining mechanism as a tool to overcome exclusion in the making and execution of security policy, and the effectiveness and sustainability of SSR programming have suffered as a result. In light of this, the paper will explore both the potential for, and the limits of, rehabilitating the notion of local ownership to enable more participatory forms of SSR, and argues that any practical local ownership strategy requires a dual policy of negotiating with state actors and engaging with non-state actors.
\end{abstract}

Since the end of the cold war, both the study and the practice of security have been in a state of turmoil. Academics and practitioners alike have struggled to come to terms with the reality of "new" security threats and with the ongoing referent object issue-neatly captured by recent debates about human security-concerning who or what is to be secured through the practices of security. No less controversial (if somewhat less prominent in academic or policy debates) is the question of the relationship between the providers and the consumers of security. Security has long been characterized by a clear (and typically gendered) divide between protector and protected, with the former enjoying a near monopoly of agency over how, and to whom, security is provided. Both in discourse and in practice, therefore, security has been not only about including and excluding particular populations, but has also been about who enjoys, and who is denied, the ability to "speak" and to "do" security. As Lene Hansen (2000) has argued in her critique of the Copenhagen School's notion of security as "speech act", "those who . . . are constrained in their ability to speak security are therefore prevented from becoming subjects worthy of consideration and protection” (p. 285). 
In recent years, a growing body of scholarship from both the human security and critical security schools has begun to challenge the conventional subject-object distinctions of security studies, along with the long-standing cult of expertise surrounding security policy and practice. Security sector reform is one of the areas in which this broader debate over agency has been playing out, particularly in the context of calls for greater local ownership over both the processes of reform and the ongoing provision of security. A relatively recent addition to the security lexicon, security sector reform (or SSR) refers to efforts to re-structure the security apparatus-including armies, police forces, judiciaries, and associated oversight mechanisms - of states emerging from war, authoritarianism, or both. Local ownership, as a concept, refers to the extent to which local actors (however defined) exercise control or influence over the initiation, design and implementation of reform processes. Taken together, then, examining security sector reform through the lens of local ownership entails asking questions about inclusion and exclusion in one prominent area of contemporary security practice.

Drawing on recent policy debates, this paper explores this broader ownership question in SSR. It suggests that there are two important conceptual divides across which local ownership questions play out: the first is between the international and the domestic, and the second is between state and non-state. On both fronts, the discourse and the practice of SSR has been exclusionary for those on the receiving end of reforms. At the same time, while the principle of local ownership has been advanced as a means of addressing and overcoming this exclusion, the ownership question has been framed in ways that largely perpetuate SSR's exclusionary nature. In light of this, the paper will explore both the potential for, and the limits of, rehabilitating the notion of local ownership to enable more participatory forms of SSR.

\section{Local Ownership and the Emerging SSR Paradigm}

Security sector reform, in the words of Sean McFate (2008), "is the complex task of reforming the 'security sector'-those organizations and institutions that safeguard the state and its citizens from security threats-into professional, effective, legitimate, apolitical and accountable actors” (p. 1). As a concept, SSR gained prominence at the end of the cold war, initially in response to the challenge of making the security structures of post-communist Eastern Europe more effective, accountable, and affordable as part of the broader transition to liberal democracy. Since then, security sector reform has come to be seen as an essential component of any successful democratic transition. This is especially true in the case of countries emerging from conflict; from Haiti to Bosnia and from Afghanistan to East Timor, the task of rebuilding (or constructing de novo) effective and accountable security institutions now occupies a prominent place in contemporary post-conflict transitions, and is increasingly accepted as a basic precondition for sustainable peacebuilding.

Apart from a few prominent exceptions (South Africa being the most notable), SSR has been predominantly a donor-driven enterprise. Donors have provided the bulk of the funding and the impetus for SSR processes, and in recent years the 
Development Assistance Committee of the Organization for Economic Co-operation and Development (OECD DAC) has emerged as a driving force in the articulation of both principle and practice on SSR issues. ${ }^{2}$ Unsurprisingly, therefore, the emerging SSR agenda has tended to reflect donor understandings and priorities, and it is no stretch to suggest that from a donor perspective, the entire SSR enterprise has been about making "their" security institutions look more like "our" security institutions. Regardless of the peculiarities of the reform context, the idealized model of SSR advanced by the donor community involves the creation/consolidation of a professional, democratically-accountable security sector guided by a "peoplecentred," public-service approach to security provision, underpinned by liberal principles of human rights and good governance (OECD, 2007, pp. 21-22).

Regardless of the merits of this overarching policy prescription-and there is little doubt that the effective implementation of the SSR vision described above would significantly enhance the human security of millions currently living under repression or in the shadow of armed conflict-SSR is also a fundamentally normative enterprise. It aims, in short, to transform societies not only through institutional engineering but also by altering basic understandings of local actors concerning the state-society relationship. Given donor control over both funding and agenda-setting, a strong streak of donor paternalism runs through much SSR programming, and SSR often appears as an exercise in externally-driven social engineering, in which outsiders "teach" local counterparts how to construct and manage a Western-style security sector. Local actors, in this reading, are not so much agents of transformation themselves as objects to be transformed.

From the perspective of both the "beneficiaries" of SSR programming and of contemporary development thinking, this view of SSR as a modern-day mission civilisatrice is far from unproblematic. On the one hand are ethical concerns about SSR imperialism, about the privileging of external knowledge and agendas over local ones, and about whether the actions of international actors are always (or ever) benignly altruistic (Woodward, 2003). On the other hand, there are also practical concerns about the sustainability of externally-driven reform processes, however well-intentioned. As Joseph Stiglitz (1998) has noted, visions of development in which all the answers and all the agency are seen to lie in the hands of outsiders are not only inherently problematic but ultimately self-defeating: "Policies that are imposed from outside may be grudgingly accepted on a superficial basis, but will rarely be implemented as intended.” In this sense, the outcomes of SSR are largely inseparable from the processes of SSR.

In response to the perceived flaws of outside-in models of SSR, there has been of late a growing and widespread recognition that local ownership is in fact a key component of successful SSR. The OECD DAC, for example, has cited local ownership as one of three overarching objectives of donor engagement in SSR (2007, p. 10). Yet despite the emergence of local ownership as part of the contemporary commonsense of security sector reform, from definitional and operational perspectives the concept remains both elastic and elusive. Considerable ambiguity persists, in particular, around the precise identity of the locals to whom the concept refers, as well as around the specific meanings of ownership.

State-centric traditions of national security have meant that the conventional response to the question of "which locals" has tended to focus on national governments of reforming states, which are assumed to possess not only the 
authority but also the legitimacy to engage in SSR. However, as Alex Martin and Peter Wilson (2008) have suggested, the absence of properly representative government in many of the countries currently undertaking SSR raises obvious questions about whether political elites are, or should be, the only relevant local owners in SSR processes (p. 84). Similarly, Annika Hansen (2008) has noted that because SSR involves redistributing the way power is exercised in a particular society, "those that are the most dominant players are also the ones least likely to be cooperative in a reform effort because they have the most to lose" (p. 44). In other words, while local political elites may be the most obvious local owners, they can also be the most problematic.

Growing recognition of such problems has led some observers to distinguish between regime ownership and national ownership (Goodhand \& Sedra, 2007, p. 54). While regime ownership refers to a commitment on the part of the formal institutions of government to reform, national ownership by contrast refers to a much broader, societal-wide embrace of, and engagement with, SSR. Civil society is typically viewed as a kind of collective national owner, and a potentially progressive counterbalance to those holding the formal reins of power (Pouligny, 2005). Yet while the notion of national ownership is in principle inclusionary, participatory, and democratic, it is no less fraught than that of regime ownership, albeit for different reasons. In particular, more maximalist conceptions of ownership tend to underestimate the extent of social fragmentation within societies undertaking SSR, while overestimating levels of non-state expertise in and engagement with security issues (Bendix \& Stanley, 2008). In addition, then, to the very practical question of how to engage society writ large in a wide-ranging debate on the future of the security sector, there is the broader challenge of achieving a minimal level of societal consensus on the shape of the security sector to be constructed.

In the field of SSR, the most precise formulation of what ownership could, and should, mean has been offered by Laurie Nathan (2007). Informed by South Africa's post-apartheid experience of security sector reform, widely viewed as both successful and as the product of a genuinely-inclusive and broad-based national process, Nathan has suggested that "the principle of local ownership means that the reform of security policies, institutions and activities in a given country must be designed, managed and implemented by domestic actors rather than external actors" (p. 4). Echoing Stiglitz, Nathan argued that in the absence of substantive local ownership, SSR is bound to fail. In contrast to the donor-driven model of SSR described above, then, Nathan's vision of locally-owned SSR puts local actors squarely in the driver's seat, with external actors relegated to a supporting and facilitating role. While the donor community might accept this vision in principleindeed OECD DAC documents draw directly on the Nathan framework-in practice there remains an ongoing and widespread unease with the notion that SSR should be fully "owned and operated" by local actors.

In many SSR contexts, this unease is justified, and advocates of a strong form of local ownership —one in which the local actors truly design, manage, and implement reforms-must confront some uncomfortable realities. The most obvious challenge is that in many states, there is little reason to believe that greater local ownership of SSR will actually lead to improved security, which is ostensibly the ultimate goal of SSR programming in the first place. Indeed, local actors may pursue SSR not out of 
a commitment to improved security governance, but rather as a means of enhancing their capacity to suppress dissent or to undermine political opponents. As I have noted elsewhere, "it is one thing to cede authority and control (over SSR decisionmaking) to committed, democratically elected, Western-oriented reformers, and quite another to do the same vis-à-vis former warlords with dubious democratic legitimacy and troubling human rights records" (Donais, 2008, p. 277). In many contexts, international security assistance remains deeply controversial precisely because of the concern that outsiders will not have sufficient control over the uses, and potential abuses, to which such assistance is applied. Even without ascribing nefarious intent to domestic elites, it is also the case that in many contexts, local actors lack the cohesion, capacity or commitment to engage in long-term structural reforms aimed at building robust and democratically-controlled security systems. To idealize local ownership, in other words, is no less problematic than to ignore it.

This debate reveals a basic tension at the heart of the emerging SSR paradigm between a commitment to the normative and institutional principles underpinning SSR and a commitment to the principle of local ownership. While this tension is muted in contexts where the relevant local actors embrace the normative framework of SSR, it emerges most clearly in those situations in which locals prove either unable or unwilling to accept these basic normative premises. As Annika Hansen has framed the issue:

If local authorities decide they would like to have a bicycle with square wheels, should the internationals allow them to have such a bicycle even though they know it won't go anywhere? Or should they insist on imposing round wheels against the wishes of their local partners? (cited in Pietz \& von Carlowitz, 2007, p. 10).

While Hansen's analogy might be fanciful—and make implicit assumptions both about the rationality of the relevant actors and the locus of decision-making authority in SSR contexts - the contemporary world of SSR provides an abundance of examples where profound tensions emerge between the principles of local ownership and those of good governance. In Afghanistan, to take one example, local influences over SSR in the post-Taliban period have led to the factionalization (both sectorally and geographically) of security governance, a trend which has run directly counter to the ongoing efforts of the international community to de-politicize and professionalize the broader security sector (Giustozzi, 2008).

While there are clear tensions with regard to what are often differing political motivations of the various actors involved in SSR processes, a more fundamental tension is also at play here. One of the core assumptions underpinning the local ownership principle is that the success of any reform process depends on the extent to which it is perceived as legitimate by those who have to live with the outcomes; this legitimacy, in turn, depends in large part on the degree to which reform processes resonate with local values, norms, and traditions (Talentino, 2007). Successful reform processes must, therefore, tread a fine line between promoting fundamental change and respecting long-standing tradition. Afghanistan's postTaliban loya jirga process represents one contemporary example of a forwardlooking reform process married to a traditional, locally-legitimate institutional framework. In most SSR contexts, however, "the local" has been seen more as problem than solution, while the universality of the norms and values attached to the 
broader SSR enterprise has tended to be taken for granted. As Eric Scheye (2008) has argued, however, “although it is the donors' ideological and normative position progressively to inculcate the values and beliefs embodied in human rights conventions and principles ... empirically it is doubtful that today Western beliefs are widely accepted or even intelligible in many fragile environments” (p. 70). What emerges, then, is a tension between a liberal-institutionalist approach to SSR, rooted in the belief that a universally-valid and legitimate set of principles and structures around security governance exists, and a corresponding communitarian perspective which holds than any successful SSR process must be carefully tailored, from initial premises on up, to fit the particular socio-cultural context in which it is to be enacted.

At the level of policy, the imperative of navigating these tensions has led not to a broader effort to reconcile liberal and communitarian positions, but rather to the emergence of an understanding of local ownership that is less challenging to the normative principles of donor-defined SSR. In contrast to the Nathan definition, in this vision locals are asked, and expected, to "take ownership over" what remains primarily an externally-defined process; local ownership, in this sense, is increasingly associated with local "buy-in." ${ }^{3}$ This semantic move is far from insignificant, as it focuses attention on the relatively narrow question of who owns the process, rather than on the broader and far more normatively-charged question of who defines the process and fills it with substantive content.

The recent experience of police reform in post-Dayton Bosnia provides one illustration of the ways in which ownership questions have played out in practice, particularly in the context of post-conflict SSR. Under the terms of the Dayton Peace Accords, policing in Bosnia is an entity-level responsibility; each of Bosnia's two ethnically-divided entities enjoy exclusive policing competency within their respective territories, and the leaders of Republika Srpska (RS) in particular see policing as a crucial foundation of the semi-sovereign status of their entity. As part of the international community's broader state-building agenda in Bosnia, however, an internationally-led Police Restructuring Commission (PRC) was established in 2004. The three core principles on which the commission's final report was basedthat budgetary and legislative authority for policing be shifted to the state level, that policing operations be free from political influence, and that policing districts be established on operational and technical (as opposed to political) criteria-directly challenged the post-Dayton status quo, even if the principles were defended in the name of de-politicizing and professionalizing policing in Bosnia (Perdan, 2008, pp. 263-64; Donais, 2006). In the face of predictable resistance from the RS, and in light of the failure to convince the RS leadership that thorough-going police reform was in their own long-term interests (paving the way for Bosnia's eventual entry into the European Union), the police reform issue became a national crisis when the EU warned that Bosnia would proceed no further along the EU accession path unless the PRC recommendations were adopted. While the RS leadership eventually buckled under enormous international pressure, it is clear that in this particular case, local ownership was less a manifestation of local agency and more a function of coercive arm-twisting aimed at securing local "buy-in." Local ownership, in this sense, appears increasingly tied to a broader conception of responsibility, in which the exercise of ownership is conditional on prior acceptance of an externally-defined set of norms, values, and in this case institutional frameworks. As Caroline Hughes and 
Vanessa Pupovac (2005) have noted in a comparative assessment of international interventions in both Bosnia and Cambodia, "while responsibility for politics is to be placed back on the shoulders of local people, this is a disciplined politics, regulated by international norms" (p. 883).

The ownership as responsibility theme also emerges in the myriad efforts to foster local ownership through longer-term processes of norms-transmission. The dominant metaphor here equates reforming states with novice drivers, with the international community playing the role of nervous parent: before the latter hands over the car keys, the former must be taught how to drive responsibly. In the area of SSR, one manifestation of this model involves the efforts of international police assistance missions to socialize police officers in developing or post-conflict states- through training, mentoring, technical assistance, and institutional development efforts-into adopting internationally-accepted norms of modern democratic policing. In this context, local ownership becomes possible only once the local subjects and institutions have been re-engineered, and ownership emerges as the desired end of any reform process, rather than as the means through which particular ends are achieved (Chesterman, 2007, p. 7).

There are, of course, some heroic assumptions-concerning both the ability of external actors to fundamentally transform transitional societies and the willingness of local actors to uncritically embrace the key normative principles of the SSR agenda-underpinning the belief that local actors can be taught, socialized or coerced into accepting an external agenda for reform. The fact that police reform in Bosnia continues to be a source of considerable contention across the internationallocal divide despite the forced agreement on core principles suggests, as Mark Baskin (2004) has noted, that even in highly intrusive international operations such as Bosnia there remains a significant gap "between unlimited formal international authority and limited international operational capacity” (p. 129). Similarly, as Alice Hills (2008) has suggested, despite increasing international pressure and assistance in the promotion of democratic policing models across sub-Saharan Africa, "most police in most African countries are fundamentally unchanged from what they were ten years ago ... politicized, under-resourced, and inadequately trained” (p. 216). Indeed, there is a growing and substantial body of empirical evidence demonstrating the limits of such outside-in processes (Nathan, 2007). In other words, in the absence of substantive local ownership (as defined by Nathan), reforms have been thinly institutionalized and SSR norms weakly internalized.

The debate over the role of local ownership in SSR processes, then, has led to something of an impasse. Regime ownership has been limited by the suspicions (sometimes well-founded) of international actors concerning the commitment of local political elites to the normative foundations of SSR, while national ownership remains limited by the sense that non-state local owners are both unwieldy as a constituency and only marginally relevant to the core concerns of SSR. On the other hand, however, there also appear to be real limits on the ability of outside-in SSR processes to remake non-Western security sectors in the absence of genuine local commitment. Clearly, therefore, any attempt at moving towards a more inclusive form of SSR, in which notions of local ownership are taken more seriously, must involve careful consideration of both the identity and the intentions of the relevant local actors. It must also involve the recognition that at its core, SSR is a dialectical process, involving a complex set of relations among international and domestic 
actors (both state and non-state) (Hills, 2008). In this relationship, none of these sets of actors is entirely unproblematic as a vehicle for effective SSR, yet all are necessary if any sustainable SSR process is to emerge.

\section{Advancing Ownership and SSR}

Any attempt to generalize about the possibilities for more substantive and inclusive local ownership in SSR processes is necessarily complicated by the immense variability of the conditions under which SSR unfolds. Indeed, the absence of wellfunctioning liberal democratic institutions may be the only shared characteristic of many reforming states. The stable, strong-state situation of Indonesia, for example, is a world away from the fragile state context of Bosnia, in terms of state capacity and political will, in terms of the level of outside engagement with SSR, and in terms of domestic perceptions of SSR's legitimacy. There is, in fact, an important distinction between post-conflict SSR processes and post-authoritarian SSR processes. In the former, international actors play a much more prominent role in initiating, designing and implementing SSR, security politics is inextricably wrapped up in the contentious politics of post-war transition and the realities of ongoing insecurity, and the regimes in power are often more concerned with day-to-day survival than with long-term structural transformation. In the latter, SSR is more likely to be regimeinitiated and is therefore less dependent on international impetus and largesse, while the state itself has greater capacity both to envision and to manage longer-term reform processes.

Despite these contextual differences, however, and the inevitably greater complications of local ownership in post-conflict settings, there is an emerging consensus that some degree of local ownership is a necessary if not sufficient condition for successful SSR. While there are important differences between the view that local actors must drive the reform process from conception to implementation and the contrasting view that local ownership is about "winning [local] acquiescence for externally generated policies” (Bendix \& Stanley, 2008, p. 95), both positions accept-implicitly or explicitly - that local ownership matters to the long-term success of reform. In the context of specific reform environments, however, both positions may suffer from excessive idealism, the former because it risks over-estimating local capacity and political will, the latter because it overestimates international capacity and political will. In what follows, I draw on the distinction between regime ownership and national ownership to make the case that any practical local ownership strategy requires a dual policy of negotiating with state actors and engaging with non-state actors.

Quite obviously, there is no avoiding the broader question of regime ownership in SSR processes. National-level governments, as trustees of the state's claim to hold a monopoly over the legitimate use of physical force, are both central and authoritative in matters of security governance. While regimes may be more or less dependent on external actors, and more or less capable of providing security for both state and citizen, even the weakest regimes are capable of exercising a de facto veto over SSR. In other words, while many states lack the capacity to plan and manage coherent and comprehensive SSR programs, domestic authorities retain considerable capacity to 
block, circumvent, and/or undermine initiatives they oppose or which threaten the interests of key domestic actors. This is, at least in part, a consequence of the reality that while outsiders can design and fund SSR programming, they remain fundamentally dependent on domestic actors in the implementation phase.

Ultimately, then, given the inherently limited capacity of outsiders to transform, replace, or circumvent domestic political elites, and given the high likelihood that SSR programming undertaken without the support of such elites will fail, undertaking effective and sustainable SSR must almost inevitably involve a negotiated partnership with the governments of reforming states. While this may seem self-evident, a number of important implications flow from this notion of SSR as negotiated partnership. First, it suggests that hierarchical donor-recipient or teacher-pupil models of SSR are misleading, since local actors (especially governments) retain considerable agency in SSR processes. It also acknowledges the reality that in any negotiated process, knowledge and information flow in both directions. As Olawale Ismail (2008) has argued, just as locals can learn from outsiders about SSR best practice, in both technical and normative terms, outsiders have much to learn from locals about the domestic political context in which reform processes must unfold. Most importantly, perhaps, conceiving of SSR in terms of a negotiated partnership points to the need for outsiders to engage local elites in a broader discussion about whether and how international norms concerning good governance in the security sector can be reconciled not only with local traditions, practices, and values, but also with the more parochial interests of elites themselves.

None of this is meant to suggest that reconciling different visions of how security should be organized or provided is a simple matter, or that difficult compromises can be easily avoided. On the question of reconciling different normative orders, for example, the debate over justice sector reform in post-Taliban Afghanistan provides a compelling example. On the one hand, there are good arguments for rooting locallevel justice processes in shuras, which enjoy considerable local legitimacy as a traditional form of dispute resolution. Others contend that because shuras tend to be comprised almost exclusively of male elders, such mechanisms should be progressively bypassed in favour of modern court systems, which may lack local legitimacy but are more consistent with principles of due process and representativeness. ${ }^{4}$ At the same time, reconciling international norms with the political interests of local elites almost necessarily implies difficult choices about whether SSR processes must work within existing domestic power structures, or whether they should be part of a broader process of transforming such structures. While there are few easy solutions to such dilemmas, it is probably fair to say that SSR practitioners have done less than they could to both understand indigenous forms of governance and explore how they might be compatible with SSR's broad normative agenda. Fortunately, many forms of democratic good governance exist, just as there is no single template for an effective security sector; the lesson here, then, is that respectful negotiation, creative problem-solving, patience and effective cross-cultural communication can be just as useful as deep pockets or technical expertise in the promotion of sustainable SSR.

While regime ownership may be a sine qua non for effective SSR, the non-state dimensions of the ownership question also matter, and may in fact represent a largely untapped resource through which international and local agendas can be reconciled. To be sure, there are formidable obstacles to achieving genuinely wide and deep 
national ownership over any SSR process. First, as noted above, ownership implies some minimal consensus on common goals, and the wider the constituency the more difficult the consensus-building process. The security sector also tends to be among the most closed and secretive arenas of national political life, while few transitional states have histories of non-state involvement in security affairs. Consequently, nonstate actors typically lack both expertise and capacity, and they face considerable obstacles in obtaining access to both information and to decision-making fora on security-related questions. Funding dependency further reduces the scope for civil society groups - the primary expressions of national ownership-to exercise substantive and independent voice over the form or content of SSR processes.

Despite these barriers, much of the contemporary literature on SSR views civil society as having a legitimate-if circumscribed-role to play in SSR processes. In most cases, civil society is seen as a potentially useful public-service watchdog, holding state security agencies accountable for corruption and other abuses of power, or as a transmission belt conveying information between the state and the wider populace. More generally, however, as Marina Caparini (2004) has suggested, "while frequently invoked in SSR circles, civil society tends to be understood superficially, discussed in narrow terms, and is the subject of little systemic research" (p. 56).

With regard to the broader debate on local ownership in SSR, then, both in theory and in practice the connections between civil society and SSR remain relatively unexplored. This is a significant issue, particularly given that SSR, as it has developed over the past decade, has arguably become at least as much about human security as about state security: If SSR is supposed to be people-centred, what then is the appropriate role for "the people" in this process? In many ways, this question gets to the heart of what SSR is all about: as Laurie Nathan has argued, beyond its more technical dimensions SSR is also both a democratic and a democratizing project, aimed at opening up the historically-closed box of the security sector and subjecting it to democratic control and oversight (2007, p. 9). Marina Caparini makes a similar point, noting that in security affairs no less than in other dimensions of political life, "the participation of citizens in decisions that affect their lives distinguishes substantive democracy from formal or procedural democracy” (2004, p. 56).

Seen through a slightly different theoretical lens, the argument for greater civil society involvement in SSR processes is also an argument for the de-securitization of the security sector. As Ole Waever (1995) has suggested, to label something a "security issue" is to lift it out of the realm of normal politics and authorize extraordinary means to address it. By its very nature, then, the entire security sector-as the agent of extraordinary means - can be seen as a domain outside of normal politics, and therefore not subject to the same sets of checks and balances that constrain other political actors and institutions. The converse of securitization, of course, is de-securitization, in which issues are downgraded from existential threats to matters of everyday politics. Calls for national ownership over SSR processes therefore represent part of a broader effort to de-securitize the politics of security provision by subjecting the security sector to greater transparency, by forcing security actors and decision-makers to be more accountable, and by broadening the scope of public involvement in security affairs. Democratizing 
security affairs through the processes of de-securitization is consistent not only with SSR's normative underpinnings but also with more substantive visions of local ownership, since the outcomes of such processes are not pre-determined, but rather subject to the interplay of domestic political forces.

There are other good arguments for expanding the boundaries of the relevant local owners to include civil society. Beyond the broader contention that civil society serves as a useful counterweight to the state, bringing to light a range of issues and concerns in an environment where state institutions and actors may not effectively represent the public interest, the ability of civil society actors to articulate their own lived experiences of security and insecurity can act as an important corrective to some of the top-down assumptions of mainstream SSR. Externally-driven SSR tends to project Western solutions onto non-Western contexts, and in the process may neglect key aspects of the security dynamic in reforming states. Carving out a greater space for civil society voices in SSR processes may not only help ensure that such dynamics are addressed, but may also help shift the focus from institutional isomorphism-replicating Western institutional frameworks in non-Western environments - to addressing the lived insecurities of real people in real places.

One template for how this might be achieved is provided by the so-called Zwelethemba model, based on a series of experiments in local security governance carried out in South Africa during the first decade after apartheid. ${ }^{5}$ Informed by a vision of security governance emphasizing "locally generated responses to locally generated questions," 6 the Zwelethemba experiments facilitated the establishment of local peace committees and peacemaking fora to respond to specific local security problems. While not SSR in an institutional sense, such experiments (similar initiatives have been undertaken in the Afghan context) ${ }^{7}$ demonstrate the potential of mobilizing local capacity and knowledge in the management of community-level security affairs. As Shearing (2001) notes, early results from Zwelethemba were promising in terms of generating locally-driven, future-focused resolutions to security problems, even if, to date, such initiatives have tended to be piece-meal and disconnected from more conventional top-down security reforms (p. 25).

Ultimately, civil society can serve as a crucial ally for the international community on SSR issues. While it would be a mistake to see civil society as necessarily benevolent and progressive, it is also the case that the vast majority of those on the receiving end of SSR programming are likely to want what donors are selling, which is the promise of better governance and improved security. A longer-term investment on the part of international donors in building civil society capacity to engage with SSR-related issues may not only serve to erode the notion that security issues are the exclusive preserve of politicians and uniformed service personnel, but may also counter-in the context of a broader democratization process-self-serving elites tempted to manipulate SSR processes for their own political ends. ${ }^{8}$ Widespread participation of "the people" in SSR processes, in other words, may provide a better long-term guarantee than abstract normative principles that security structures will in fact be "people-centred." 


\section{Conclusion}

As the debate on security sector reform has evolved, the notion of local ownership has come to serve as much as a disciplining mechanism as a tool to overcome exclusion in the making and execution of security policy. While donors and international institutions pay lip service to the idea that locals should be in the driver's seat when it comes to planning and implementing reforms to their security sectors, the practical implementation of this vision has been hampered by the widespread belief that the locals don't know how to drive. As a result, substantive versions of local ownership have given way to shallower notions of ownership focusing on responsibility, in which a commitment to a liberal-democratic set of norms and institutions becomes a condition for local ownership. In this sense, local ownership becomes less about local authorship and control than about getting domestic actors to buy into what remains largely an externally-defined vision.

A basic premise of this paper has been that local actors can neither be ignored, bypassed, nor easily transformed. While it is increasingly accepted that some degree of local ownership is a prerequisite for sustainable SSR, the notion of SSR as a form of externally-driven social engineering ultimately leading to a locally-owned security sector which is democratically-controlled and human rights oriented both overestimates international capacities and under-estimates potential domestic resistance. While it would be neither realistic nor wise to advocate that donors support illiberal or undemocratic SSR processes - or that donors simply provide blank cheques to reforming governments and hope for the best-this paper has suggested that considerably more flexibility is required if the tensions between SSR (as currently constituted) and local ownership are to be successfully navigated. Such flexibility could be generated by focusing on the core principles of security and participation. This suggests, on the one hand, emphasizing enhanced security as the core underlying goal of SSR, while recognizing the myriad routes and mechanisms through which the goal of enhanced security can be achieved. It also suggests, on the other hand, the importance of widespread and meaningful participation in SSR processes. Participation enhances legitimacy, broadens the range of potential supporters of a "people-oriented" form of SSR, reduces the likelihood of elite capture, and enhances the possibilities for reconciling local practices and traditions with basic international norms. Participatory SSR-involving ongoing engagement and dialogue among international actors, host governments, and domestic civil society-is almost by definition messy, time-consuming, and open-ended, but is also democratic in the more substantive sense of the term and represents an alternative route to a sustainable, locally-owned security sector that effectively merges the topdown with the bottom-up.

From the donor perspective, making the transition to more participatory, inclusive forms of SSR will be a major challenge for a least two reasons. First, the bureaucratic structures and processes of most donor agencies are not particularly amenable to a more substantive conception of local ownership. In short, donors increasingly demand value for money in terms of concrete, measurable results within relatively short timeframes, and the vision of participatory SSR outlined above is unlikely to produce such outcomes, even if the outcomes it does produce may ultimately be more sustainable. A second reason for scepticism is that as much as 
SSR is a normative project, it is also a political one. Particularly as SSR is increasingly linked to the broader goals of the war on terror, donors may increasingly be pursuing SSR in transition countries for their own security interests. In contrast, then, to Edward Joseph's recent defence of “dispassionate outsiders” (2007, p. 110), given the range of interests at play in SSR contexts donors may be increasingly tempted to insist on their own solutions rather than defer to-or at least negotiate with-local owners. As Bendix and Stanley warn, "calling for an enhancement of local ownership and less control for donors is perhaps naïve when one considers that SSR was conceptualized by donors in order to gain access to security matters" in transitional states (2008, p. 101-2).

Despite these concerns, however, it seems clear that the debate over local ownership in security sector reform processes is not going away. Thinking through how local ownership may be most effectively fostered and sustained, therefore, remains an important challenge, particularly as the gap between ambition and outcome in SSR processes remains wide, and as recipients become increasingly disillusioned by the gap between donor rhetoric about ownership and donor actions on the ground.

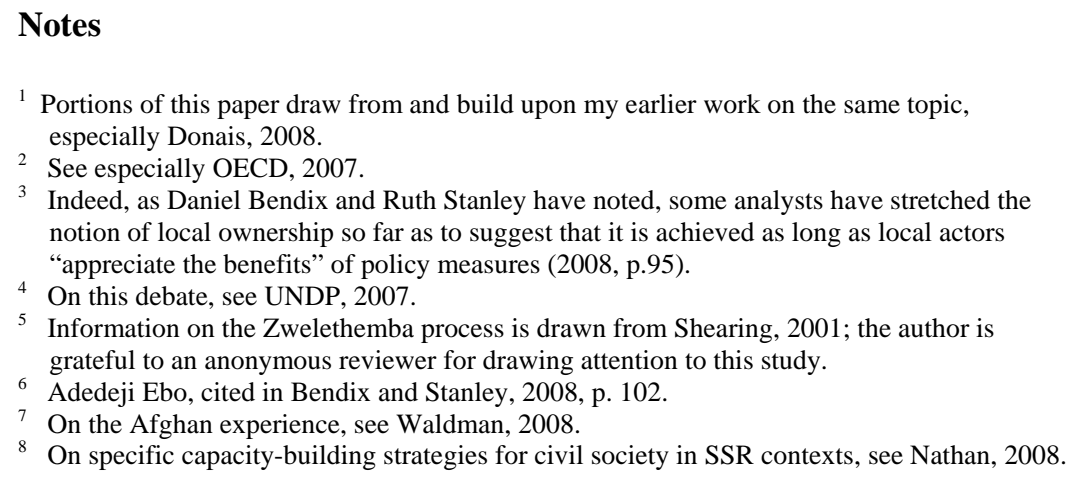

\section{References}

Baskin, M. (2004). Between exit and engagement: On the division of authority in transitional administrations. Global Governance, 10, 119-137.

Bendix D. \& Stanley, R. (2008). Deconstructing local ownership of security sector reform: A review of the literature, African Security Review 17(2), 93-104.

Caparini, M. (2004). The Relevance of civil society. In C. McCartney, M. Fischer, \& O. Wils (Eds.), Security sector reform: Potentials and challenges for conflict transformation (pp. 53-61). Berghof Handbook Dialogue Series No. 2. Berlin: Berghof Center for Constructive Conflict Management; available at: http://www.berghof-handbook.net

Chesterman, S. (2007). Ownership in theory and in practice: Transfer of authority in UN statebuilding operations. Journal of Intervention and Statebuilding, 1(1), 3-26.

Donais, T. (2006). The limits of post-conflict police reform. In M. Innes (Ed.), Bosnian security after Dayton: New perspectives (pp. 173-190). London/New York: Routledge.

Donais, T. (Ed.). (2008). Local ownership and security sector reform. Zurich/Berlin: Lit Verlag for the Geneva Centre for Democratic Control of Armed Forces (DCAF). 
Giustozzi, A. (2008). Shadow ownership and SSR in Afghanistan. In T. Donais (Ed.), Local ownership and security sector reform (pp. 215-232). Zurich/Berlin: Lit Verlag for the Geneva Centre for Democratic Control of Armed Forces (DCAF).

Goodhand, J., and Sedra, M. (2007). Bribes or bargains? Peace conditionalities and 'post-conflict' reconstruction in Afghanistan. International Peacekeeping, 14(1), 41-61.

Hansen, A. (2008). Local ownership in peace operations. In T. Donais (Ed.), Local ownership and security sector reform (pp. 39-58). Zurich/Berlin: Lit Verlag for the Geneva Centre for Democratic Control of Armed Forces (DCAF).

Hansen, L. (2000). The Little Mermaid's silent security dilemma and the absence of gender in the Copenhagen school. Millennium, 29, 285-306.

Hills, A. (2008). The dialectic of police reform in Nigeria. Journal of Modern African Studies, 46(2), 215234.

Hughes, C., and Pupavac, V. (2005). Framing post-conflict societies: International pathologisation of Cambodia and the post-Yugoslav states. Third World Quarterly, 26(6), 873-889.

Ismail, O. (2008). Enabling local ownership: Participation and capacity-building in SSR. In T. Donais (Ed.), Local ownership and security sector reform (pp. 127-145). Zurich/Berlin: Lit Verlag for the Geneva Centre for Democratic Control of Armed Forces (DCAF).

Joseph, E. (2007). Ownership is over-rated. SAIS Review, 27(2), 109-123.

Martin, A., \& Wilson, P. (2008). Security sector evolution: Which locals? Ownership of what? In T. Donais (Ed.), Local ownership and security sector reform (pp. 83-103). Zurich/Berlin: Lit Verlag for the Geneva Centre for Democratic Control of Armed Forces (DCAF).

McFate, S. (2008). Securing the future: A primer on security sector reform in conflict countries. US Institute of Peace Special Report 209. Washington: US Institute of Peace. Retrieved from www.usip.org

Nathan, L. (2007). No ownership, no commitment: A guide to local ownership of security sector reform. Birmingham: University of Birmingham Press.

Nathan, L. (2008). The challenge of local ownership of SSR: From donor rhetoric to practice. In T. Donais (Ed.), Local ownership and security sector reform (pp. 19-35). Zurich/Berlin: Lit Verlag for the Geneva Centre for Democratic Control of Armed Forces (DCAF).

Organization for Economic Co-operation and Development (OECD). (2007). The OECD DAC handbook on security system reform: Supporting security and justice. Paris: OECD Publishing.

Perdan, S. (2008). Bosnia: SSR under International Tutelage. In T. Donais (Ed.), Local ownership and security sector reform (pp. 253-272). Zurich/Berlin: Lit Verlag for the Geneva Centre for Democratic Control of Armed Forces (DCAF).

Pietz, T., and von Carlowitz, L. (2007). Local ownership in peacebuilding processes in failed states: Approaches, experiences, and prerequisites for success. Report on an Expert Meeting, Center for International Peace Operations (ZIF), Berlin, 20-21 April 2007. Retrieved from http://www.zifberlin.org/fileadmin/uploads/analyse/dokumente/veroeffentlichungen/Local_Ownership_Workshop_Re port_Dezember_07.pdf

Pouligny, B. (2005). Civil society and post-conflict peacebuilding: Ambiguities of international programmes aimed at building 'new' societies. Security Dialogue, 36(4), 495-510.

Scheye, E. (2008). Unknotting local ownership redux: Bringing non-state/local justice networks back in. In T. Donais (Ed.), Local ownership and security sector reform (pp. 59-81). Zurich/Berlin: Lit Verlag for the Geneva Centre for Democratic Control of Armed Forces (DCAF).

Shearing, C. (2001). Transforming security: A South African experiment. In H. Strang \& J. Braithwaite (Eds.), Restorative justice and civil society (pp. 14-34). Cambridge: Cambridge University Press.

Stiglitz, J. (1998). Towards a new paradigm for development: Strategies, Policies and processes. The 1998 Prebisch Lecture. Geneva: UNCTAD. Retrieved from http://siteresources.worldbank.org/CDF/Resources/prebisch98.pdf

Talentino, A. (2007). Perceptions of peacebuilding: The dynamic of imposer and imposed upon. International Studies Perspectives, 8, 152-171.

United Nations Development Program (UNDP). (2007). Afghanistan human development report 2007. Kabul: UNDP/Center for Policy and Human Development.

Waever, O. (1995). Securitization and de-securitization. In R. Lipschutz (Ed.), On security (pp. 46-86). New York: Columbia University Press.

Waldman, M. (2008). Community peacebuilding in Afghanistan: The case for a national strategy. Oxford: Oxfam. Retrieved from

www.oxfam.org/en/policy/briefingnotes/community_peacebuilding_in_afghanistan_report_feb08 
Woodward, S. (2003). In whose interest is security sector reform? Lessons from the Balkans. In G. Cawthra \& R. Luckham (Eds.), Governing insecurity: Democratic control of military and security establishments in transitional democracies (pp. 276-302). London/New York: Zed Books. 